\title{
Dramatic shift: Conservative to Avant-garde in Sarah Kane’s “4.48 Psychosis”
}

\author{
Cambio dramático: De conservador a vanguardista de Sarah Kane en "4.48 Psychosis"
}

Emmerencia Sih Beh

The University of Bamenda - Cameroon

North West Region, Cameroon

emme.brava@yahoo.com

\section{Abstract}

Drama is a genre in literature that recreates not only existing actions but also interprets the different versions of truth put on stage. Sarah Kane, a dramatist, is usually associated with the new theatrical form of writing called the in-yer-face theatre. Kane, after writing her last play, 4.48 Psychosis, commits suicide. For this reason, many critics consider this play a 'suicide notes' which makes it limiting since these critics do not pay attention to her extensive use of styles and her experimental shift from conservative to avant-garde dramatic constructions. While her earlier works Blasted, Phaedra's Love, and Cleansed were centred principally on shock irritating violent and relatively hostile metaphors, the style of her two last plays Crave and 4.48 Psychosis shifts blatantly as they are written in a conspicuously poetic style. Her last play which is the focus of this study swings from conventional to the unconventional style of writing given that she deviates from the classical presentation of drama. This study uses the theoretical backdrop of Postmodernism for its analysis. The paper demonstrates that analysing 4.48 Psychosis in connection to Kane's life and death is restrictive and biased as it procures a plethora of innovative scopes. It, therefore, assesses how dramatic experimentation is used to expose some of the recurrent themes in contemporary drama.

Keywords: Dramatic, conservative, avant-garde, Postmodernism, Sarah Kane

\section{Resumen}

El teatro es un género de la literatura que recrea no sólo las acciones existentes, sino que también interpreta las diferentes versiones de la verdad puestas en escena. A Sarah Kane, dramaturga, se la suele asociar con la nueva forma de escritura teatral llamada teatro in-yer-face. Kane, tras escribir su última obra, 4.48 Psychosis, se suicida. Por esta razón, muchos críticos consideran esta obra como "notas de suicidio", lo que la limita, ya que estos críticos no prestan atención a su amplio uso de estilos y a su cambio experimental de construcciones dramáticas conservadoras a vanguardistas. Mientras que sus primeras obras, Blasted, Phaedra's Love y Cleansed, se centraban principalmente en metáforas violentas y relativamente hostiles, el estilo de sus dos últimas obras, Crave y 4.48 Psychosis, cambia de forma evidente, ya que están escritas en un estilo claramente poético. Su última obra, en la que se centra este estudio, oscila entre un estilo de escritura convencional y otro no convencional, ya que se desvía de la presentación clásica del drama. Este estudio utiliza el telón de fondo teórico del posmodernismo para su análisis. El trabajo demuestra que analizar 4.48 Psicosis en relación con la vida y la muerte de Kane es restrictivo y tendencioso, ya que procura una plétora de alcances innovadores. Por lo tanto, evalúa cómo la experimentación dramática se utiliza para exponer algunos de los temas recurrentes en el drama contemporáneo

Palabras clave: Dramaturgia, conservador, vanguardia, Postmodernismo, Sarah Kane 


\section{Introduction}

Sarah Kane is a postmodernist British female playwright who has been greatly influenced by Aleks Sierz's contemporary dramatic/ theatrical trend called the In-yer-face theatre. Her writings have brought a lot of polemics from the beginning when she first published Blasted - this gets to its climax when she commits suicide after writing her last play 4.48 Psychosis. Raised in a Christian home, Kane later fights with her belief as she grows up and discards it entirely, though subjects like God and faith are still found in some of her plays. She enrolled in Masters class for Playwriting with David Edgar at the Birmingham University in 1992, but later discovered that it was going to break her focus as she "wanted to invent new forms [and] try what hasn't been tried so far" (Sierz, 1999, p. 92). The desire to create a new form of writing pushes her to embark on playwriting.

\subsection{Postmodernism, Postmodernity and Literature}

Postmodernism can be defined as a style in architectural art, literature and criticism established after and frequently in response to modernism, characterized by reference to other styles in an uncomfortable way and an imitation of the concept of high art. The prefix post emphasises the relation to the previous period and the opposition to it at the same time. The term postmodern was used for the first time in the 1950 s and 6os to define a new architectural movement, which was in contrast to the former modern style. (Lakeland, 1997, p. 2). Emmanuel Njume Ekindesone in his distinction between Postmodernism and Postmodernity in "Postmodern Culture and Identity in Saul Bellow's Ravelstein" says:

Postmodernism would, therefore, infer artistic connotations, particularly geared towards experimenting avant-garde forms; while postmodernity would suggest cultural implications that cut across global and local phenomena; including but not limited to feminism in social discourse, Ecocriticism, minority questions, self and other debates and cultural and individual identity crisis. (Ekindesone, 2014, p.159)

Postmodernism encourages creativity, especially the ones that test unconventional style. Consequently, it does not admit conventionality in any case because it limits resourcefulness. Unlike Postmodernism, Postmodernity deals with the effect of this new form of modernism universally. In the same light, Nick Kaye in Postmodernism and Performance thinks that,

The postmodern [drama] indicates a calling into question of the languages, styles and figures through which it is seen... It follows that the postmodern in art is subversive and transgressive, that is occurs as a critical and skeptical stepping beyond bounds, a disruption that purposefully upsets the terms by which the "work of art" would constitute itself. (Kaye, 1994, p. 19)

Postmodern drama questions the way language is used by the playwright, his/her style of writing, the presentation of the work, and the use of certain features or structures. The writings of these writers are rebellious, as they deconstruct the roles and presentation of mainstream drama. Postmodernists make an effort to take away the voice from the author and give the readers the opportunity to interpret texts. Rosenau (1993) argues that, "No longer is the reader a passive subject to be entertained, instructed or amused. He/she is given the freedom to attribute meaning to the text without consequence or responsibility." (Rosenau, 1993, p.25) The postmodernist maintains that no two texts or two readings of the same text are ever identical, and if this is indeed the case, individuals would be responsible for the many different texts and readings.

\subsection{Sarah Kane's 4.48 Psychosis}

4.48 Psychosis is Sarah Kane's last play which was published posthumously in 2001. While writing the play, Kane was going through hopelessness which caused her to be hospitalized frequently. According to Mark Ravenhill, she saw no value in life anymore and started contemplating suicide. This thought of hers is achieved when she finally commits suicide. Before her suicide, she left a number of letters instructing her friends, colleagues and family to do whatever they wanted to do with the play [4.48 Psychosis] with the understanding that writing the play destroyed her. This action pushes many critics to analyse her text in connection to her suicide, though her brother, Simon, upholds that it is just a play on 'social despair' like 
any other play. An instance of such criticism is evident when the play was premiered in 2000, and most of the critics left with the assumption that they were watching a "70-minute suicide note" (Singer, 2004, p. 160). This reproach takes another shape when Dan Rebellato writes in "Sarah Kane - An Appreciation" that "it would be a second tragedy if her death were to become an easy way of not confronting the seriousness of her work" (Rebellato, 1999, p. 281). Rebellato, therefore, thinks that it will be better to explore other areas in Kane's 4.48 Psychosis other than suicide. This study searches new zones to project different ways of dramatic presentation other than the canonical ones.

\section{Methods}

Each investigation has as an obligation to include a clear, methodical and systematic approach to discover the most suitable result. The study makes use the qualitative method of data collection with Sarah Kane's 4.48.Psychosis as its main text of analysis. This method collects and interprets data from the literary text [4.48.Psychosis] and its co-texts in order to bring out new meaning. It equally aids in the understanding of the social, political, cultural, theoretical and historical position from which the text is written. This helps to identify new ways to understand earlier works and fills the gaps that exist in previous research. After the reading of books, articles, book chapters, theses and internet sources connected to this scholarship, the study takes a snapshot of the different interpretations and criticisms of Kane's play and comes up with alternative ways of viewing her play. The article, therefore, focuses on Kane's dramatic shift from tradition to experimental, using her 4.48. Psychosis as the main text, coupled with other texts for its investigation.

\section{Sarah Kane's 4.48 Psychosis and its Dramatic Shift}

Sarah Kane, a postmodernist and one of the leading figures of the In-Yer-Face theatre, breaks away from the classical convention of dramatic writing and creates a new form of writing which is experimental in nature. In her new form of writing, she strives to destroy the distance between the audience/reader and the stage/text. Through the use of language, she succeeds in bringing out different subjects and meanings in her plays. Her postmodern style of always disgusting the audience and not giving them comfort at the end of either watching or reading her plays can be likened to Lyotard's ideology when he states that, postmodernism,

...puts forward the unpresentable in presentation itself; that which denies itself the solace of good forms, the consensus of taste which would make it possible to share collectively the nostalgia for the unattainable; that which searches for new presentations, not in order to enjoy them but in order to impart a stronger sense of the unpresentable (Lyotard, 1984, p. 81)

Actions that may be considered unpresentable are made possible on stage in a postmodern writing or (re)presentation. Such writings don't find comfort in what the classicists see as a good style of writing. Sarah Kane's plays are a perfect example of what is considered the "unpresentable" which is now made possible on stage. Such presentations are linked to some young dramatists who rose in the 1990 so introduce a new awareness on the British stage. Some of the playwrights are: Mark Ravenhill, Anthony Neilson, Rebecca Prichard, and Sarah Kane. Their writings did not have any limitation in their subject or forms. They go as far as exploring what is seen as taboo subjects. Their hostile modes of representation in which the audience/reader senses and reacts, with the realities staged tags them in the theatrical form that Aleks Sierz calls the in-yer-face.

In his In-Yer-Face Theatre: British Drama Today, Aleks Sierz defines it in its broadest sense: "In-Yer-Face Theatre is any drama which "grabs the audience by the scruff of the neck and shakes it until it gets the message. It is a theatre of sensation: it jolts both actors and spectators out of conventional responses, touching nerves and provoking alarm" (Sierz, 2001, p.4). This drama is a responsive one in which the readers/ audience react as they are touched by the message. The messages of such dramas are more realistic than the way reality itself is presented. Here, the spectators/readers are not just there to enjoy the storyline, but they are touched by their reality which they even see as disgusting and violent when represented. This group, according to Naomi Klein, "was a generation of Thatcher's children who employed new formal dramatic structures to confront political realities in post-Thatcher Britain by presenting shocking forms of violence, explicit sex and crude language" (Klein, 2007, p.232). The writers through language expose the 
predicaments in their society like violence, capitalism and inequality. By using violence on stage or graphic violence in books, the writers aim at shocking the reader/audience with what seems to be unacceptable or unpresentable.

Kane in her plays exposes graphic violence through the use of language. By presenting graphic violence and violence on stage, Kane's intention is to expose the effect of it in the world, and consequently, discourage it from happening in real life. In an interview with Rodolfo di Giammarco, Kane explains:

[...] Violence is the most urgent problem we have as species, and the most urgent thing we need to confront. Personally, I say there is nothing better to write about. I don't like violent films, that's true, and I don't like violent scenes; and the reason I don't like violence is when I happen to see Reservoir Dogs, Pulp Fiction or the other films of that type I feel like using violence. When I wrote Blasted I tried to discuss what it means to be violent and to suffer violence, and it's like the music that's played when you're cutting off an ear. You are in a state of extreme suffering; it's not possible you can like it for the music. (Giammarco, 1997)

The postmodern society is characterised by unpleasant actions. Kane presents this cruelty in her plays as most of her characters are victims of hostility and brutality. She tries to get her readers/audience not to be ignorant of the atrocities of life since there is a lot of violence between humans and animals, which maybe more than that of animals. Violence is presented in Kane's 4.48 Psychosis through the use of words:

Oh dear, what's happened to your arm?

I cut it.

That's a very immature, attention seeking thing to do. Did it give you relief?

No.

Did it relieve the tension?

No. (A long silence.)

Can I look?

No.

I'd like to look, to see if it's infected.

No. (Silence.)

I thought you might do this. Lots of people do. It relieves the tension.

Have you ever done it?

No. Far too fucking sane and sensible. I don't know where you read that, but it does not relieve the tension. (Silence.)

Why don't you ask me why

Why did I cut my arm? ...

Why did you cut your arm?

Because it feels fucking great. Because it feels fucking amazing

Can I look?

You can look. But don't touch. (Kane, 1999, p. 10-12)

From her words, the speaker goes through psychological as well as physical pain. Her action may be as a result of betrayal. She accuses the doctor of treachery and ends up using a blade to harm herself. The doctor that she is supposed to depend on for her health is not reliable. In this way, she sees no reason to live and decides to brutally harm herself. Though she gets no relief for her action, she exposes that her violent action is great and amazing. The patient's refusal for her arm not to be cut off may be because of the physical pain she feels. Psychologically, she is not fine too given that the person she is to look up to is tagged a betrayal. The patient exposes other violent actions when she states:

I gassed the Jews, I killed the Kurds, I bombed the Arabs, I fucked small children while they begged for mercy, the killing fields are mine, everyone left the party because of me, l'll suck your fucking eyes out sent them to your mother in a box and when I die I'm going to be reincarnated as your child only fifty times worse and as mad as all fuck I'm going to make your life a living fucking hell I REFUSE I REFUSE I REFUSE LOOK AWAY FROM ME. (Kane, 1999, p.19) 
The patient in the scene exposes the horrible happenings in her society where children are raped, people killed and bombed. The imagery is not different from the cruel images painted in Blasted and Cleansed. The sucking of the eye here can be compared to the incidence in Blasted where the Soldier sucks out the eyes of lan and renders him blind. The brutal action of the speaker causes everyone to leave the party since they are unable to contend with the brutality. The speaker affirms the position of a killer which shows that killing his fellow brothers and sisters means nothing to him. Gassing the Jews and bombing the Arabs may show his/her discrimination against the other race or religion. This brings out the idea of race and religious differentiation in which he/she sees himself/herself superior to others and sees their lives worthless.

Another aspect in which Kane experiments on is the title of her plays. The titles of her plays Blasted (1995), Phaedra's Love (1996), Cleanse (1998), Crave (1998) and 4.48Psychosis (2000) make use of parts of speech like verbs, nouns. It also connotes other instances of the text that help in bringing out the meaning. Kane specifies an exact time in her play 4.48 Psychosis. One may be forced to ask what happened at that time. In the introduction of Kane's Complete Plays, David Greig says that 4.48 is the time that Kane used to get up to write her plays. The 4.48 of the title has a contradictory meaning. It may refer to 4:48 AM when "sanity visit" (Kane, 1999, p. 20) and in another instance, it may refer to 4:48 AM "when depression visits" (Kane, 1999, p. 4). The speaker mentions the same time at which two contradictory things happened to her:

At 4.48

When sanity visits

For one hour and twelve minutes I am in my right mind.

When it has passed, I shall be gone again,

A fragmented puppet, a grotesque fool. (Kane, 1999, p. 20-21)

The speaker affirms that, at 4:48, she gets her sanity for one hour, twelve minutes. That is, between 4:48 to 6:00 AM. After that period, things will change and she will get back to her depressed state:

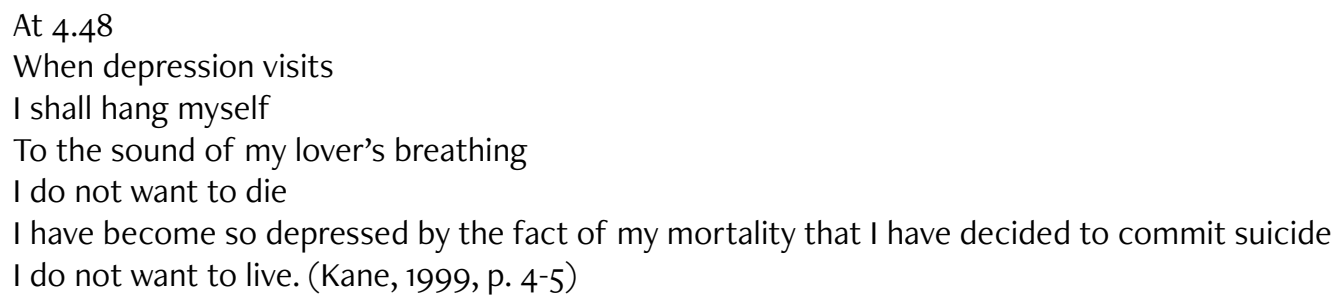

According to the speaker, 4.48 when she is at the highest point of depression. Though she doesn't really want to die, her depressed state will not permit her to live. This depression has caused her not to know what she wants for herself and thinks that suicide is a better option. 4.48 is mentioned in the play four times. The first is when depression visits Kane (1999, p. 4), and she states that at this instance, she wants to hang herself as she doesn't desire life anymore. We see 4.48 the second time when she says: "After 4.48 I shall not speak again (Kane, 1999, p. 9). These still points towards death since she doesn't see any value for life in that condition. The third time, she mentions 4.48 "when sanity visits"(Kane, 1999, p. 20). At this point, she is fine for one hour, twelve minutes-no suicidal intentions. This is the time she has calmness. She mentions 4.48 the last time again when she says: “At 4.48/I shall sleep" (Kane, 1999, p. 23). At this time, there is still stillness and soundness in which she is able to stay at ease and even sleeps.

Like in Kane's other plays, the word "fuck" is used in 4.48 Psychosis thirty-five times. The speaker uses the word at will. In one of the extracts of the play, she uses the word thirteen times just for a short passage:

Fuck you. Fuck you. Fuck you for rejecting me by never being there, fuck you for making me feel shit about myself, fuck you for bleeding the fucking love and life out of me, fuck my father for fucking up my life for good and fuck my mother for not leaving him, but most of all, fuck you God for making me love a person who does not exist, FUCK YOU FUCK YOU FUCK YOU. (Kane, 1999, p. 13) 
The speaker expresses her frustration which comes with different reasons: for being rejected, for looking down on herself because of influence, she has been made to feel worthless, the trauma of either being raped or treated poorly by her father, the fact that her mother is unable to leave her father in spite his action, and lastly, for being pushed to love someone (God) whom she believes doesn't exist. Contrary to Phaedra's Love where vulgar language is used to express mixed feelings of surprise, anger and happiness, the speaker in 4.48 Psychosis uses such words to express anger and frustration. Jay (1992) thinks that men use offensive words more than women:

Both speaker gender and age affect word choice and frequency; men swear more frequently in public than women. Men accounted for $67 \%$ of public swearing episodes in 1986, but the gap narrowed to $55 \%$ by 2006 . Men say more offensive words (e.g., fuck, shit, motherfucker) more frequently than women do. Women say oh my god, bitch, piss, and retard(ed) more frequently than men do. In fact the mild expletive oh my god accounted for $24 \%$ of the women's 2006 data and women were five times more likely than men to say it. Men and women swear more frequently in the presence of their own gender than in mixed-gender contexts. (Jay, 1992, p. 9)

I disagree with Jay who thinks that men use offensive words more in public than women, but agree with him that both gender swear more frequently in the presence of their own gender. The word "fuck" is used by both males and females in Kane's plays.

Furthermore, Kane makes use of a limited number of characters, stage directions and dialogue. There isn't any specific number of characters in 4.48 Psychosis. Sarah Kane gives her reason for reducing everything about her play: "I wanted to strip everything down. I wanted it to be as minimal and poetic as possible. I didn't want to waste any words" (Sierz, 2001, p. 116). Kane sees the making of her work to be a wastage of words since she is able to incorporate everything in her thoughts in fewer words. Contrary to her other plays, Kane's 4.48 Psychosis has no character's name, setting or stage directions. The dialogue in the play indicates that there are different characters. Though the gender is not mentioned, one is likely to associate the main speaker with being a female character. She interacts with a male character who is a therapist and with other inmates, her fellow patients. Other portions of the play look more like a monologue. Kane does not like the development of drama and theatre in which theatre goers keep accommodating the old style and are comfortable with the same thing they watch daily:

I hate the idea of theatre just being an evening pastime. It should be emotionally and intellectually demanding. I love football. The level of analysis that you listen to on the terraces is astonishing. If people did that in the theatre... but they don't. They expect to sit back and not participate. If there's a place for musicals, opera or whatever, then there should be a place for good new writing, irrespective of box office. (Saunders, 2009, p. 15)

The traditional presentation of drama has also been a concern of Kane, who thinks that there should be playwrights who should get out of the box and come up with something new. She argues that people should not just go to the theatre to have leisure; rather, they should also take part in the realities of the society as presented through staging - theatre and drama are worth more than entertaining people. Readers and the audience are expected to take part in taking part as they read or watch the play being performed. They should be able to give their analysis of it and not just go to a hasty conclusion because others are in the same position. Kane writes a dramatic piece which seems challenging but exciting given that it has no character, setting or stage direction. Unlike classical drama which defines good drama as one with acts and scenes, stage directions, dialogue, and setting, Kane's 4.48 Psychosis deviates from the traditional norms and brings out something different. In her discussion, she highlights the use of characters in the plays of Kane, Saunders, in Theatre of Extreme highlights:

There is only one character in both of those plays [Crave and 4.48 Psychosis], despite the number of voices present...There is a narrative both in Crave and in 4.48 Psychosis, but there is not really what I would call 'character'. When you abandon character you abandon drama, so for me she has effectively abandoned drama....there is a diminishment of dramatically viable image structure in both of the last two plays, which renders them, for me, viable works of experimental literature rather than viable works of drama. (Saunders, 2002, p. 131) 
The fact that Kane does not name her characters in these plays doesn't mean there are no characters. Where we have dialogues in the plays, one can decipher the different expressions from the different speakers, as a result, drama has not been abandoned in that aspect, rather, the playwright has transformed old styles to suit what she wants, and also brings other new techniques to match with her intentions:

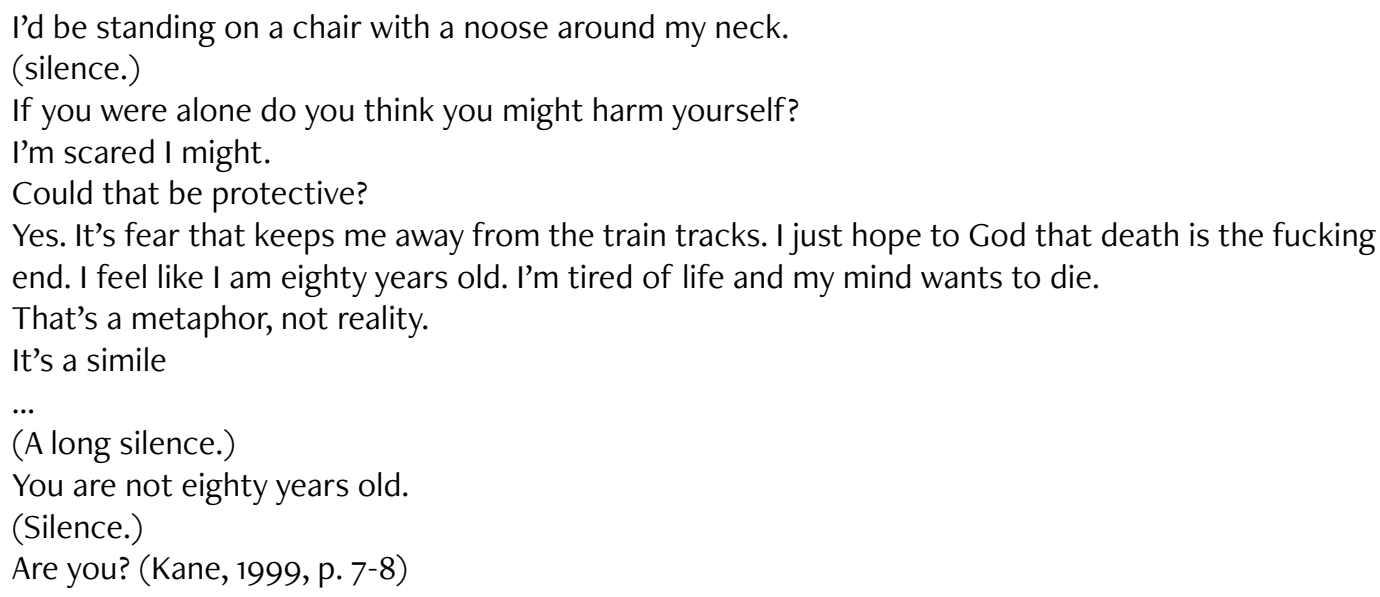

The dashes at the beginning of each expression stand for different characters in communication. The dialogue shows that there are two people in the scene: one is depressed and the other is okay. The depressed character contemplates hanging herself. This foreshadows what is going to happen at the end of the play where she takes her own life because of unreciprocated love which causes her depression and makes her desire death. In the same light, Karoline Gritzner in "Adorno and Modern Theatre: The Drama of the Damaged Self in Bond Rudkin, Barker and Kane" states that:

...the play [4.48 Psychosis] presents an added challenge due to the fact that it does not contain any specified characters - the play for this reason resembles a dramatic poem rather than a play, even though there are moments of dialogue. However, the dialogue as much as everything else in the play can be envisaged as taking place in the consciousness (or indeed the unconscious mind) of the speaker. (Gritzner, 2015, p. 158)

From the dialogue and a poetry-like structure, one may deduce that this play has a speaker, which can be the protagonist of the play. Mariia Haatanen in "The Effects of Medicalization, Medical Practices, and Mental Disorder on the Subjective Experience of the Self in Sarah Kane's 4.48 Psychosis" states that the character in 4.48 Psychosis "has no names at all, and there are no markings to tell which character is speaking each time. [...]. There is no evidence as to how many characters or speakers there are supposed to be in the play, and whether all the voices belong to different characters" (Haatanen, 2015, p.4). This protagonist is likely to be a female patient. The other major character one may get should be the doctor, her therapist who is supposed to look after her, yet he doesn't see her as an equal. This doctor should be a man, who sees his position, gender and stage superior to that of the patient(s) he is to look after. From the dialogue, one can also affirm that there are other minor characters who may be likened to other patients in the same hospital as the speaker of the play. Kane doesn't tell the number of characters in the play, neither is their gender mentioned. This study attributes the main speaker to be a woman, her therapist a man, and the mixture of male and female characters for the other patients. Carolina Sanchez Palencia Carazo in "4.48 Psychosis: Sarah Kane's bewildered fragments" states that "in this text there are neither characters nor indications for actors or setting, but only [...] unidentified voices" (Carazo, 2013, p. 2-3).

4.48 Psychosis has twenty-three scenes. These scenes can only be identified with the use of dashes. Some portions of the play can be identified as a dialogue in which there is an exchange between a doctor and his patient. Other instances are more of a monologue in which the patient, in her insane state says things the way they came up: 
(Silence.)

I fucking hate this job and I need my friends to be sane.

(Silence.)

I'm sorry.

-It's not my fault.

-I'm sorry, that was a mistake.

-It's not my fault.

No. It's not your fault. I'm sorry.

(Silence.)

I was trying to explain

-I know. I'm angry because I understand, not because I don't. (Kane, 1999, p. 27)

The short dashes in the preceding dialogue indicate the voices of different characters while the long dash is the transition from one scene to another. This discussion shows the interaction between the doctor and his patient. The Doctor's reaction shows that he is not a man of the people, given that he prefers his friends to be well-balanced, whereas his job warrants him to be friendly to everyone no matter the situation. The fragmented structure can tell that the speaker is not okay. She expresses her frustration through words and action. This frustration maybe as a result of her mental state, the system, her rejection or unreciprocated love. Some scenes just have a list of drugs or words while others have numbers randomly placed. Mariia Haatanen in "The Effects of Medicalization, Medical Practices, and Mental Disorder on the Subjective Experience of the Self in Sarah Kane's 4.48 Psychosis" states that the play "is distinctly postmodern in style and content with its fragmented and ambiguous nature" and it is "the shortest and the most fragmented of Kane's plays" (Haatanen, 2015, p. 3).

Fragmentation is an important factor/technique in postmodern writings which has been exploited by Kane in her plays. Martina Chramosilová in “Beyond the Suicidal Despair: An Analysis of Sarah Kane's 4.48 Psychosis", states that:

The fragmentation of the text corroborates the fragmentation of the patient's mind as "[her]
mind is the subject of these bewildered fragments." The words are scattered on the page as if
they were scattered on the patient's mind, but there still is some order in it, even if it may seem
chaotic at first. The individual scenes are divided by a series of dashes "- - - - -", dialogues
take frequent, almost cyclical turns with monologic and poetic passages. Kane's use of gaps and
silences is equally as important as other features of the text. (Chramosilova, 2013, p. 23)

Moreover, Kane avoids using punctuations and capitalisations in some parts of the play. She does not separate some phrases, clauses and sentences with punctuations, rather, she makes use of spaces, indentations and gaps in some sentences to make it different from the others. In some sentences or areas in the text, she makes use of capital letters, where everything in the sentence is written in capital letters. Other words are either bold or put in italics to distinguish them from others: "Don't let this kill me/this will kill me and crush me and send me to hell" (Kane, 1999, p. 18)

In 4.48 Psychosis, the protagonist seems to be fed-up with life at the beginning and starts contemplating suicide. At the early stage of the play, the main character's feeling of alienation and abandonment causes her to see life worthless and she starts talking about death. The situation becomes worse when she is abandoned by the same person she looks up to for help. Life becomes so boring to her and causes her to see herself as a failure who may never improve on herself. At this this point, she is already contemplating suicide though we are not told how and when she will do it:

I am sad

I feel that the future is hopeless and that things cannot improve.

I am bored and dissatisfied with everything

I am a complete failure as a person.

I am guilty, I am being punished

I would like to kill myself. (Kane, 1999, p. 4) 
The depressed character feels dissatisfied with everything around and sees death as the only option. Out of frustration, she decides to cut herself and causes harm to her own body. Due to humiliation and depression, she expresses her desire to take an overdose, slash her wrists, and then hang herself. This desire comes to pass towards the end of the play in which the protagonist commits suicide. The suicide comes as a result of unreciprocated love. She tells us that "the vital need for which I would die/to be loved" (Kane, 1999, p. 31). The fact that she is not being loved, or being taken care of, makes her see nothing interesting in living. She finally commits suicide at the end of the play when she states that "watch me vanish" (Kane, 1999, p. 33). Kane in this play, like in Phaedra's Love only narrates the suicide scene without showing the audience/readers how, when and where it happens.

Kane also makes use of the Serial sevens test chart in her presentation of 4.48 Psychosis. The presentation of the number is an indication of the mental state of the protagonist. One scene shows that her state is really bad while another scene shows her improvement. According to Evans, the numbering in the text is very essential:

Both numbers start at a hundred, and the first [set of] numbers [in scene 4] are completely random. The second numbers [in scene 20] come down from the hundred in regular sevens. Apparently, it's an exercise that psychiatric nurses give patients to assess their level of concentration. [...] If you can do it regularly then your concentration is fine. So obviously on the first set of numbers she's way off. (Saunders, 2009, p. 175-76).

Psychiatric nurses use the Serial sevens as a way of assessing the psychological problem of their patients. When the patient does the counting regularly without errors, it means that his/her psychological state is balanced, but when it is irregular, it means it is not balanced, and this may need extra attention. The patient's situation is seen as critical if he/she cannot even identify the number or place them in their rightful order. At this point, the psychiatrist is supposed to undertake an extra follow-up of the patient to ensure an improvement in his/her state. The charts below indicate the different levels of the patient's mental state: 
This chart is a test for someone whose mental state is imbalanced. If a psychiatric patient is given this chart and he/she counts in sevens chronologically, it is an indication that there is great improvement in his/her health. The chart above shows that the patient's psychological state is crucial and needs special medical care which is not given to her. In scene twenty, one realizes there is an order as the patient experiences some improvement in her health:

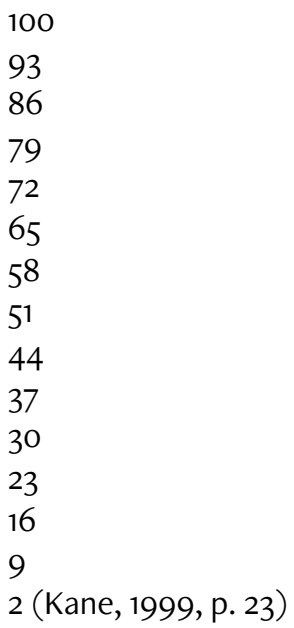

The second chart shows the improvement of the patient's health as she is able to follow the serial seven order without any difficulty. Unlike the first chart that is randomly scattered on the pages without any indication of the correct figures, the second chart is well organised as it follows the figures of the medical serial seven chart which continually adds seven to the given number as a means of testing the mental of someone with a psychological problem.

Other techniques Kane makes use of in her plays are: silence and long silence. The play 4.48 Psychosis begins with "a very long silence" followed by a "long silence" then "silence" as clear in:

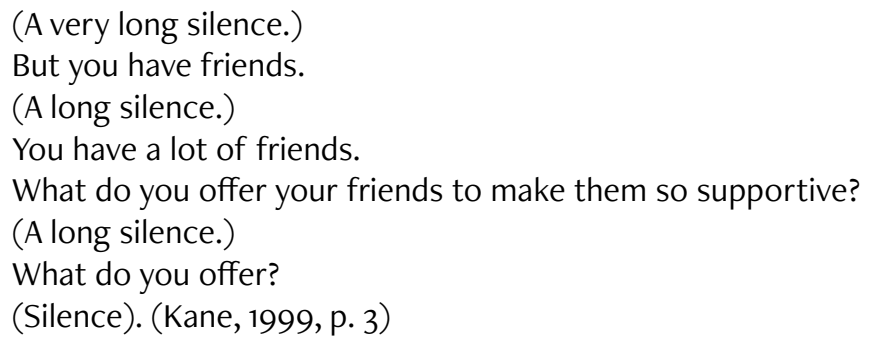

There are about 50 silences, long silence and very long silence in the play. There are other silences that can be in the form of a gap or blank page. Campbell comments on the silence used by Kane at the end of the play in which there are just two-line dialogue and a blank page: "The silence Kane imposes here through the blank space on the page is heavy with its own corporeality" ("Experiencing" 88). The different pauses, dashes, blank spaces and silences are an indication for the readers/audience to take a break and make sense of what he /she is viewing or reading. Before the one blank page towards the end of the play, the protagonist reiterates on the fact that she will vanish: "watch me vanish" (Kane, 1999, p. 33). Though blank space is the offstage suicide of the patient who is unable to bear the predicament of life, she prefers death. Kane in this scene does not stage how she commits the suicide, but her last words are recorded, as she closes the chapter of her life with "please open the curtains" (Kane, 1999, p. 35).

The playwright also makes use of repetition in her plays. The repetitions in 4.48 Psychosis can be seen in the recurrence of words and phrases like "No hope", "I REFUSE", "she'll still be dead" and "How do I stop". The phrase "No hope" is repeated in the play six times, "I REFUSE" and "she'll still be dead" are repeated twice, while "How do I stop" is repeated eight times. Repetitions are also indicative in its synonymic nature. There is the use of replaceable words like "each, every, all", "true, right, correct", "anyone and anybody". 
The playwright also uses repetition in prefixes: "unpleasant/unacceptable/uninspiring", "irrelevant/ irreverent/irreligious", "irrational/irreducible/ irredeemable" and "derailed / deranged / deform" (Kane, 1999, p. 15-16). This may be to avoid the repetition of the same words all the time. These words may speak differently when used in different perspectives rather than using the same word over and over. Rosa in "Language of a Broken Mind: Suicidal Poetic Techniques and Dramatic Dialogue in 4.48 Psychosis" states that, "Repetition seems to be the main strategy for Sarah Kane to make the dialogue work". (Rosa, 2014, p. 11) The repetition of words has a fundamental effect in the psychology of the character. The protagonist may be repeating words because of the failure of her memory which also indicates her mental state. According to Lacan, "repetition has a major significance in a psychosis. It is given as an impulse. The psychotic tends to repeat acts and words constantly, producing a disorganization of the mind" (Lacan, 2001, p. 11). The disorganisation of one's mind may result to repetition of words and actions.

\section{Conclusion}

Kane's 4.48 Psychosis is carved in a poetry-like manner. In the play, characters are not named, the acts and scenes cannot be easily identified; it also has limited stage directions. Unlike the conventional presentation of drama that sees the elements of drama as its core to presentation, postmodern drama doesn't have a particular trend or roadmap to follow. In this play, Kane uses techniques that are either new or recreated from old ones. Her shift from classical structure demonstrates her capability as a woman who can experiment dramatic techniques of writing which go beyond mainstream culture, and as such, promotes the English culture, while wiping out stereotypical views held that women cannot write good drama because they are not creative. This study cannot claim to have exhausted all the techniques use by Kane in this text, and will therefore recommend future researchers to look into her use of language, diction and the presentation of sentences to bring out meaning. By doing this, other techniques will be discovered, hence, giving room for further research.

\section{REFERENCES}

Carazo, C. S. (2013). 4.48 Psychosis: Sarah Kane's Bewildered Fragments. BELLS: Barcelona English Language and literature. 15. 1-9 https://raco.cat/index.php/Bells/article/view/82967

Chramosilova, M. (2014). Beyond the Suicidal Despair: An Analysis of Sarah Kane's 4.48 Psychosis. [Bachelor's thesis]. Masaryk University. https://is.muni.cz/th/i35wa/

Ekindesone E. N. (2014). Postmodern Culture and Identity in Saul Bellow's Ravelstein. Epasa Moto: A Multidisciplinary Journal of Arts, Letters and the Humanities of the University of Buea. 1(2). 118-177.

Giammarco, R. (September 16, 1997). Interview with Sarah Kane.

Greig, D. (2001). Introduction. In S. Kane. Sarah Kane. Complete Plays. (pp. 9-28). Methuen.

Gritzner, K. (2015). Sarah Kane or how to "scrape a life out of the ruins". In K. Gritzner. Adorno and Modern Theatre: The Drama of the Damaged Self in Bond, Rudkin, Barker and Kane. Palgrave Macmillan. https://doi. org/10.1057/9781137534477_6

Haatanen, M. (2015). The Effects of Medicalization, Medical Practices, and Mental Disorder on the Subjective Experience of the Self in Sarah Kane's 4.48 Psychosis" Tampere University: Institutional Repository.

Kane, S. (1995). Blasted. Bloomsbury.

Kane, S. (2001). “Phaedra’s Love”. In Sarah Kane Complete Plays. (pp. 61-97). Methuen.

Kane, S. (1999). 4.48 Psychosis. Methuen.

Kane, S. (1998). Cleansed. Methuen Drama.

Kane, S. (2001). “Craved”. Sarah Kane Complete Plays. (pp. 98-124). Methuen.

Kane, S. (2001). Complete Plays. Methuen.

Kaye N. (1994). Postmodernism and Performance. Palgrave Macmillan.

Klein, N. (2007). The Shock Doctrine. Penguin Books.

Lakeland, P. (1997). Postmodernity: Christian Identity in a Fragmented Age. Minneapolis.

Lehmann, H. (2006). Postdramatic Theatre. Trans. Karen Jürs-Munby. Routledge. 
Lyotard, J. (1984).The Postmodern Condition: A Report on Knowledge. Manchester University Press.

Malpas, S. (2005). The Postmodern. Routledge.

Malpas, S. (2001). Postmodern Debates. Palgrave.

Ravenhill, M. (Feb. 1999). Obituary: Sarah Kane. The Independent. Independent Digital News and Media. http://www. independent.co.uk/arts-entertainment/obituary-sarah-kane1072624.html

Ravenhill, M. (October 12, 2005). 'Suicide Art? She’s Better than That' The Guardian. http://www.theguardian.com/ stage/2005/oct/12/theatre

Rebellato, D. (2009). BLASTED: The Life and Death of Sarah Kane. Dir. Nicola Swords. Prod. Nicola Swords. http://www. danrebellato.co.uk/sarah-kane-documentary

Rabellato, D. (1999). Sarah Kane: An Appreciation. New Theatre Quarterly, 15(3), 280-281. http://doi.org/10.1017/ So266464X00013063

Rousnau, P. (1993). Post-Modernism and the Social Sciences: Insights, Inroads, and Intrusions. Princeton Press

Saunders, G. (2009). About Kane. Faber and Faber.

Saunders, G. (2002). Love Me or Kill Me. Manchester University Press.

Sierz, A. (2001). In-Yer-Face Theatre: British Drama Today. Faber and Faber.

Singer, A. (2004). Don't Want to Be This: The Elusive Sarah Kane. TDR: The Drama Review 48(2), 139-171. https://www. muse.jhu.edu/article/168268

Urban, K. (2001). An Ethics of Catastrophe: The Theatre of Sarah Kane. PAJ: A Journal of Performance and Art 23(3), 36-46. https://www.muse.jhu.edu/article/25826

\section{AUTHOR}

Emmerencia Sih Beh. PhD candidate in Literatures in English in the University of Bamenda, Cameroon, where she is also a part-time lecturer. She did her B.A and M.A in Literatures in English from the University of Buea, Cameroon, and has contributed a poem in the Anglophone Anthology titled Bearing Witness: Poems from the Land of Turmoil edited by Dibussi Tanda and Joyce Ashuntantang.

\section{Conflict of interest}

No potential conflict of interest is reported by the author.

\section{Funding}

No financial assistance from parties outside this article

\section{Acknowledgments}

$N / A$ 